\title{
Properties of the transient outward, ultra-rapid delayed rectifier and acetylcholine-sensitive potassium currents in isolated atrial myocytes from dogs: sinus rhythm and tachypaced model of permanent atrial fibrillation
}

\author{
Zsófia Kohajda, Attila Kristóf, Péter P Kovács, Claudia Corici, László Virág, Viktor Juhász, Zoltán Husti, István Baczkó, \\ András Varró, Norbert Jost ${ }^{*}$
}

From 17th Scientific Symposium of the Austrian Pharmacological Society (APHAR). Joint meeting with the Hungarian Society of Experimental and Clinical Pharmacology (MFT)

Innsbruck, Austria. 29-30 September 2011

\section{Background}

Atrial fibrillation (AF) is a common and severe arrhythmia, which largely affects quality of life. State-of-the-art treatment of AF still relies heavily on pharmacological modalities. Therefore, the aim of the present study was to investigate and compare the properties of three repolarizing currents which contribute to AF-induced remodeling, i.e. the transient outward $\left(\mathrm{I}_{\mathrm{to}}\right)$, ultra-rapid delayed rectifier $\left(\mathrm{I}_{\mathrm{Kur}}\right)$ and acetylcholine-sensitive potassium currents $\left(\mathrm{I}_{\mathrm{K}}\right.$ $\mathrm{ACh}$ ) in isolated atrial myocytes obtained from normal (SR) and tachypaced model of permanent atrial fibrillation (ATR) dogs.

\section{Methods}

The tachypaced atrial fibrillation model was performed in dogs. Transmembrane ionic currents were investigated by applying the whole-cell patch clamp technique at $37^{\circ} \mathrm{C}$, and ECG was recorded in conscious dogs.

\section{Results}

In all atrial canine myocytes, we have identified an $\mathrm{I}_{\text {to }}$ current sensitive to 4-aminopyridine (4-AP; $3 \mathrm{mM}$ ). The current inactivation was best fitted by two exponentials. The $\mathrm{I}_{\text {to }}$ current was slightly downregulated in ATR cells

\footnotetext{
* Correspondence: jost@phcol.szote.u-szeged.hu

Department of Pharmacology and Pharmacotherapy, University of Szeged; Division of Cardiovascular Pharmacology, Hungarian Academy of Sciences, 6720 Szeged, Hungary
}

when compared with that recorded in SR cells. The $\mathrm{I}_{\text {Kur }}$ current, measured as sustained current $\left(\mathrm{I}_{\text {sus }}\right)$, was upregulated in ATR dogs. However, the selective $\mathrm{I}_{\mathrm{Kur}}$ blocker 4-AP $(50 \mu \mathrm{M})$ did not block either $\mathrm{I}_{\text {sus }}$ or $\mathrm{I}_{\text {Kur }}$ "like tail" currents, which questions the reliability of these results. $\mathrm{I}_{\mathrm{K}, \mathrm{ACh}}$ was activated by the cholinergic agonist carbachol (CCh; $2 \mu \mathrm{M})$. In SR, CCh activated a large current either at inward or outward directions. The selective $\mathrm{I}_{\mathrm{K}, \mathrm{ACh}}$ blocker tertiapin (10 $\mathrm{nM})$ blocked the CCh-induced current by $57 \%$. In atrial myocytes from ATR dogs we could measure the presence of a constitutively active $\mathrm{I}_{\mathrm{K}}$, $\mathrm{ACh}$, which could be blocked by $26 \%$ with $10 \mathrm{nM}$ tertiapin. However, in ATR atrial myocytes, CCh in addition could also activate a significant ligand-dependent and tertiapine-sensitive $\mathrm{I}_{\mathrm{K}, \mathrm{ACh}}$ current. Tertiapin effectively prevented burst-induced AF in conscious ATR dogs.

\section{Conclusions}

The presence of the constitutively activated $I_{K, A C h}$ in atrial myocytes from ATR dogs shows that electrical remodeling developed in our model; this was further supported by the inducibility of AF by rapid atrial bursts in these dogs. The $\mathrm{I}_{\mathrm{K}, \mathrm{ACh}}$ current (both ligand-dependent and constitutively active currents) seems to play a significant role in the canine atrial electrical remodelling, and may be a promising drug target for suppressing AF. 


\section{Acknowledgements}

This work was funded by grants from OTKA (CNK-77855, K-82079) and the National Development Agency (TÁMOP-4.2.1/B-09/1/KONV-2010-0005).

Published: 5 September 2011

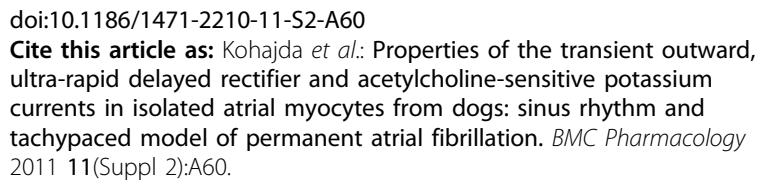

Submit your next manuscript to BioMed Central and take full advantage of:

- Convenient online submission

- Thorough peer review

- No space constraints or color figure charges

- Immediate publication on acceptance

- Inclusion in PubMed, CAS, Scopus and Google Scholar

- Research which is freely available for redistribution

Submit your manuscript at www.biomedcentral.com/submit 